\title{
Use of Electronic Waste Concrete for Road 츴 Construction
}

\author{
Aniket Ravindra Ingole, Shweta Kailashrao Gulhane, Shivani Sanjay Shirbhate, Mayur Pandit Chavhan, \\ Toshini Narendra Makde
}

\begin{abstract}
In this exploration study the investigation of an electronic waste material that we will utilize by beyond any doubt procedure and use in construction. With the advancement of the street exchange and developing traffic on streets, construction materials have also been developed and extra whimsical fixings are consolidated. The materials thus we tend to zone unit furnished with supportive and profitable information concerning these materials. The Electronic wastes have a few endowments over customary/conventional materials and techniques. This undertaking can lead an examination on work electronic waste and blending it with Concrete to get streets in India and contrast and the natural and financial conditions some of these materials zone unit similarly less expensive and supply extra quality when contrasted with antiquated street materials. This examination can return up with accommodating information and making mindfulness among the student inside the exchange concerning waste issue. All together that one will have a stage towards progressively explained information concerning these materials as have the option to execute on field which can without a doubt improve the degree of construction.
\end{abstract}

Keywords: Electronic waste, Concrete pavement, Recycling, Construction material.

\section{INTRODUCTION}

Electronic waste is all over in today's life-style. It's was generated from rejected, discarded and improper electronic or electrical equipment results in formation of waste electrical and electronic equipment's generally not used for any purposes. With the economic revolution, production of merchandise started and electronic waste gave the impression to be a more cost-effective and operative material. Moreover, every crucial part of the economy beginning from agribusiness to bundling, automobile, building construction, been about altered by the utilizations of correspondence or Info-tech has electronic wastes [1]. Electronic waste in a few kind is discovered, that is hurtful in nature. It's ordinarily gathered each urban and rural region.

Revised Manuscript Received on June 15, 2020.

* Correspondence Author

Aniket Ravindra Ingole*, Department of Civil Engineering, G.H. Rasoni University, Amravati, India. E-mail: Aniketingole11@gmail.com

Shweta Kailashrao Gulhane, Department of Environmental Engineering, College of engineering Pune, Pune, India. E-mail: shwetakgulhane@gmail.com

Shivani Sanjay Shirbhate, Department of Civil Engineeing, Jawaharlal Darda Institute of Engineering and Technology, Yavatmal, India. E-mail: shivanishirbhate06@gmail.com

Mayur Pandit Chavhan, Department of Civil Engineering, Jawaharlal Darda Institute of Engineering and Technology, Yavatmal, India. E-mail: Mayurchavhan0106@gmail.com

Toshini Narendra Makde, Department of Civil Engineering, Jawaharlal Darda Institute of Engineering and Technology, Yavatmal, India.

(C) The Authors. Published by Blue Eyes Intelligence Engineering and Sciences Publication (BEIESP). This is an open access article under the CC BY-NC-ND license (http://creativecommons.org/licenses/by-nc-nd/4.0/)
It makes stagnation of water and related cleanliness issues. Electronic waste risk to the setting. Electronic waste might be reused productively inside the construction of road [2].

\section{MATERIALS AND METHODS}

The examination will be having two different kinds of examples, the blend of Electronic waste ash remains and cement street pavement and conjointly the plain cement road pavement. Including this, to have the option to grow such examples, all totally various procedures will be done next to the testing forms the example may bear. Fly Electronic waste ash, cement, totals, and water square measure the materials of the principal example and conjointly indistinguishable materials required for the second example however at this point Electronic waste ash isn't engaged [3]. These materials unit gathered or assembled starting and conjointly the work of scoops, the materials square measure blended on board certain proportioning. When the materials unit blended, the rectangular and tube shaped molds should as of now be readied [4]. Above all, take tests from the blend that is in a situation to be utilized for the droop take a look at. When the blending method, the blend square measure put among the molds. a whole of twelve rectangular examples and twelve tube shaped examples unit advancing to made, six in each sort and two or three examples in each kind unit advancing to be tried for its compressive and malleable pressure [5]. Then the specimens bear the method for the aim of the association. Throughout the 7, 14 and 21 days, the molds square measure removed, and by now, the specimen's square measure tested. Take a glance at results square measure obtained, thus interpretation ought to be done [6].

Blue Eyes Intelligence Engineering

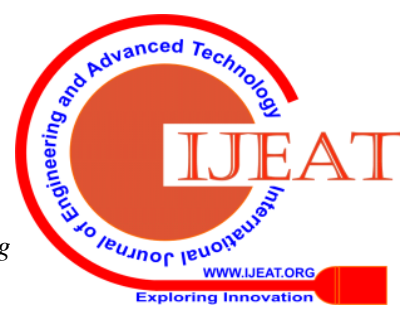




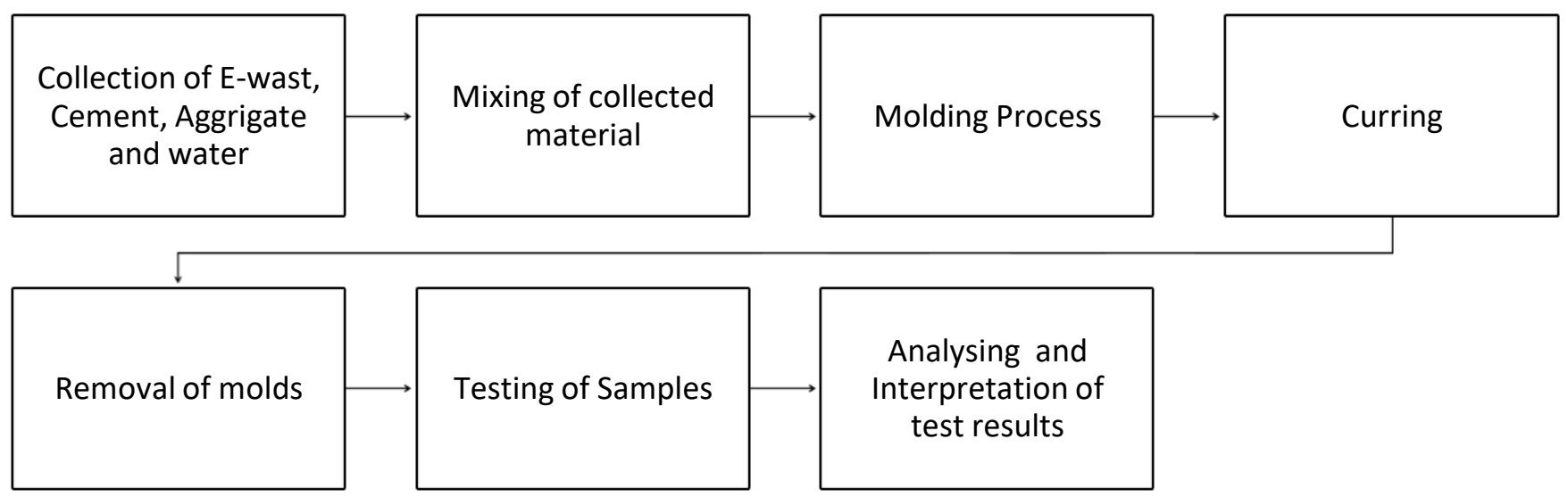

Fig 1: Schematic Diagram of Electronic waste Concrete pavement Construction and testing.

The investigation is all with respect to creating ash for concrete street pavement. Completely various tests square measure coming to be depleted request that the examiner may separate the anticipated undertaking from a standard cement-concrete blend [7]. The anticipated comes square measure coming to be electronic waste ash and cementconcrete blend and plain cement-concrete blend. Initial, an area of the examination would be the get-together or gettogether of the materials [8]. The materials to be used amid this examination unit of estimation sand, rock, bond, fiery remains, and water. The rock is additionally a blend of $3 / 7 "$, $3 / 5$ " and $1 / 3$ " sizes. The thickness of ash would be gotten by utilizing a pycnometer. The assurance of thickness can confirm the offer of a void. The consistency of the blend is then checked by a droop check. In the event that the droop of the blend is bigger than the predetermined, at that point alteration the blend proportioning [9]. On the off chance that the flexural and compressive quality of cinder and concrete examples' unit of estimation on high of the bond examples, at that point the blend of powder and bond is further prudent as far as development contrasted with the plain bond. On the elective hand, if it's lower, the blend proportioning should be changed [10].

\section{RESULTS AND DISCUSSION}

\subsection{Components of Plain Concrete and E-waste Ash and Cement Concrete}

The chemical and physical properties of materials utilized amid this investigation square measure recorded in Table one [12]. The ash was identified as a powdery, fine molecule that includes a high lime $(\mathrm{CaO})$ in its content that helps go about as a fastener to hold the totals parts on. The sand was seen as a permeable shake comprising grain of sand that has obtainable size [13].

used in construction with the sieve analysis of 160 Measure utilized in construction with the sifter investigation of 160 um, 550 um and $1.15 \mathrm{um}$. Inside the rock, there's a small low shake part that incorporates a size of $12 \mathrm{~mm}, 14.5 \mathrm{~mm}$ and $17.5 \mathrm{~mm}$ made of crystalline substance compound while concrete was characterized as dark powder processing plant produced using rock [11].

Table 1: Physical and Chemical Properties of Materials Used.

\begin{tabular}{|c|c|c|}
\hline Materials & $\begin{array}{l}\text { Physical } \\
\text { property }\end{array}$ & Chemical property \\
\hline $\begin{array}{l}\text { Electronic } \\
\text { waste ash }\end{array}$ & $\begin{array}{l}\text { Powder particles } \\
\text { containing fine } \\
\text { particles, } \\
\text { spherical in } \\
\text { shape. Either } \\
\text { solid or hollow } \\
\text { and mostly } \\
\text { glassy in nature. }\end{array}$ & $\begin{array}{l}\text { Polyethylene, } \\
\text { silicon, glassy } \\
\text { compound, copper, } \\
\text { aluminium } \\
\text { components in } \\
\text { combination with } \\
\text { other non-metals. }\end{array}$ \\
\hline sand & $\begin{array}{l}\text { Porous rock } \\
\text { consisting grains } \\
\text { of sand or fine } \\
\text { aggregate it has } \\
\text { an available size } \\
\text { of } 160 \text { um, } 550 \\
\text { um and } 1.15 \text { um }\end{array}$ & $\begin{array}{l}\text { Clay and silica } \\
\text { which gives } \\
\text { characteristic } \\
\text { colours for } \\
\text { cementitious } \\
\text { substance }\end{array}$ \\
\hline Gravel & $\begin{array}{l}\text { Small pebbles of } \\
\text { rock fragments } \\
\text { has coarser than } \\
\text { sand have an } \\
\text { available size of } \\
3 / 7 \text { ", } 3 / 5 \text { " and } \\
1 / 3 \text { "' }\end{array}$ & Crystalline silica \\
\hline Cement & Greyish powder & $\begin{array}{l}\text { Limestone or chalk } \\
\text { clay which has } \\
\text { characterized as } \\
\text { paste component }\end{array}$ \\
\hline
\end{tabular}

The mix degree of models is seemed Table 2. The degree used is 1:2:4 shown for strong black-top. Volume of each unrefined material is taken per $\mathrm{m} 3$ of strong mix [14].

Published By:

Blue Eyes Intelligence Engineering DOI: 10.35940/ijeat.E7028.069520

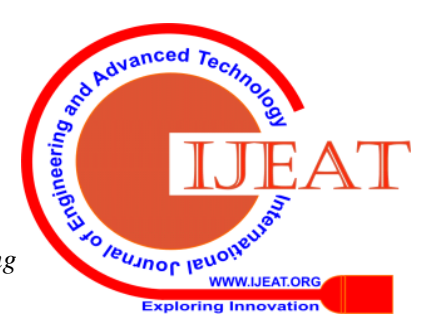


Table 2: Mix Proportion of Specimens

\begin{tabular}{|c|c|c|}
\hline \multirow{2}{*}{$\begin{array}{c}\text { Raw } \\
\text { Materials }\end{array}$} & \multicolumn{2}{|c|}{$\begin{array}{c}\text { Volume per cubic meter of } \\
\text { concrete mixture }\end{array}$} \\
\cline { 2 - 3 } & $\begin{array}{c}\text { Plain cement } \\
\text { concrete }\end{array}$ & $\begin{array}{c}\text { Electronic waste } \\
\text { ash and cement } \\
\text { concrete }\end{array}$ \\
\hline Cement & $0.15 \mathrm{~m}^{3}$ & $0.1 \mathrm{~m}^{3}$ \\
\hline Sand & $0.30 \mathrm{~m}^{3}$ & $0.30 \mathrm{~m}^{3}$ \\
\hline Gravel & $0.55 \mathrm{~m}^{3}$ & $0.55 \mathrm{~m}^{3}$ \\
\hline $\begin{array}{c}\text { E-waste } \\
\text { ash }\end{array}$ & - & $0.05 \mathrm{~m}^{3}$ \\
\hline $\begin{array}{c}\text { Total } \\
\text { Volume }\end{array}$ & $1.0 \mathrm{~m}^{3}$ & $1.0 \mathrm{~m}^{3}$ \\
\hline
\end{tabular}

The blend extent of plain bond solid example is appeared in Figure 2. The extent utilized is 1:2:4 such for solid asphalt. The diagram speaks to one metric limit unit of plain bond solid blend partitioned into extent of crude materials utilized [15]. The examples were formed in rectangular molds.

\section{Mix Proportion of Plain Concrete Specimen}

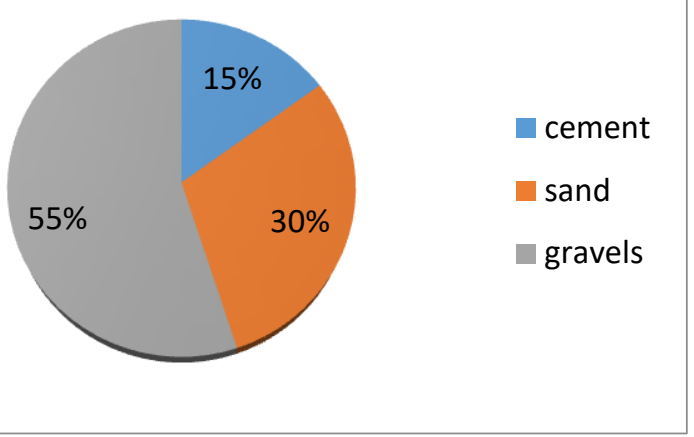

Fig 2: Mix Proportion of Plain Concrete Specimen The genuine weight and estimation of rectangular models used in this examination are recorded in study are recorded in Table 3. The precedent was tossed in a rectangular structure about $160 \mathrm{~mm}$. x $160 \mathrm{~mm}$. x $500 \mathrm{~mm}$. Each model is weighed before testing in the comprehensive testing machine [16].

Table 3: Actual Weight and Dimension of the Rectangular Specimens

\begin{tabular}{|c|c|c|c|c|c|c|}
\hline Days & Specimen & Length (mm) & Width(mm) & Height (mm) & Area $\left(\mathrm{mm}^{2}\right)$ & $\begin{array}{l}\text { Weight } \\
\text { (kg) }\end{array}$ \\
\hline \multicolumn{7}{|c|}{ Plain Concrete } \\
\hline \multirow[t]{3}{*}{7} & A & 500 & 155 & 140 & 21700 & 25.0 \\
\hline & $\mathrm{B}$ & 500 & 156 & 139 & 21684 & 24.8 \\
\hline & $\mathrm{C}$ & 497 & 153 & 136 & 20808 & 23.5 \\
\hline \multirow[t]{3}{*}{14} & A & 496 & 154 & 138 & 21252 & 25.6 \\
\hline & $\mathrm{B}$ & 495 & 152 & 140 & 21280 & 23.9 \\
\hline & $\mathrm{C}$ & 499 & 155 & 139 & 21545 & 24.8 \\
\hline \multicolumn{7}{|c|}{ E-waste ash and Cement Concrete } \\
\hline \multirow[t]{3}{*}{7} & A & 498 & 153 & 138 & 21114 & 25.1 \\
\hline & $\mathrm{B}$ & 500 & 156 & 140 & 21840 & 24.7 \\
\hline & $\mathrm{C}$ & 496 & 155 & 138 & 21390 & 23.9 \\
\hline \multirow[t]{3}{*}{14} & A & 500 & 154 & 139 & 21406 & 24.6 \\
\hline & B & 499 & 153 & 137 & 20961 & 25.1 \\
\hline & $\mathrm{C}$ & 497 & 155 & 140 & 21700 & 24.9 \\
\hline
\end{tabular}

3.2: Mechanical Properties of Plain Concrete and e-waste Ash and Cement Concrete

Table 4: Specific Gravity Test Results of e-waste Ash

\begin{tabular}{|c|c|c|c|}
\hline Number of Trails & 1 & 2 & 3 \\
\hline $\begin{array}{c}\text { Weight of pycnometer } \\
\text { Water (g) Wa }\end{array}$ & 69.7 & 68.9 & 69.5 \\
\hline $\begin{array}{c}\text { Weight of pycnometer + } \\
\text { water + E-waste ash (g) } \\
\text { Wb }\end{array}$ & 72.3 & 71.5 & 72.6 \\
\hline $\begin{array}{c}\text { Weight of dry e-waste } \\
\text { ash Wo }\end{array}$ & 11 & 10.8 & 10.7 \\
\hline $\begin{array}{c}\text { Specific Gravity } \\
\text { Wo/Wo+(Wa-Wb) }\end{array}$ & 1.30 & 1.32 & 1.48 \\
\hline Average Specific Gravity & & 1.37 & \\
\hline
\end{tabular}

The relative explicit gravity consequence of concrete and e-waste ash is shown in

Table 4, the particular gravity of e-waste ash is lower than that of concrete. Explicit gravity is 3 while e-waste ash is 1.37 .

Published By:

Blue Eyes Intelligence Engineering

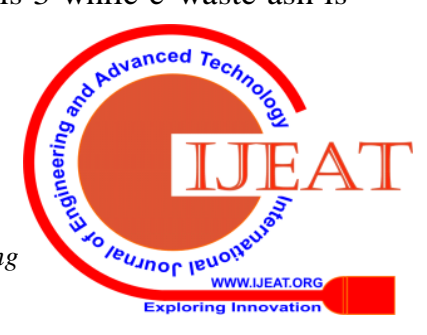




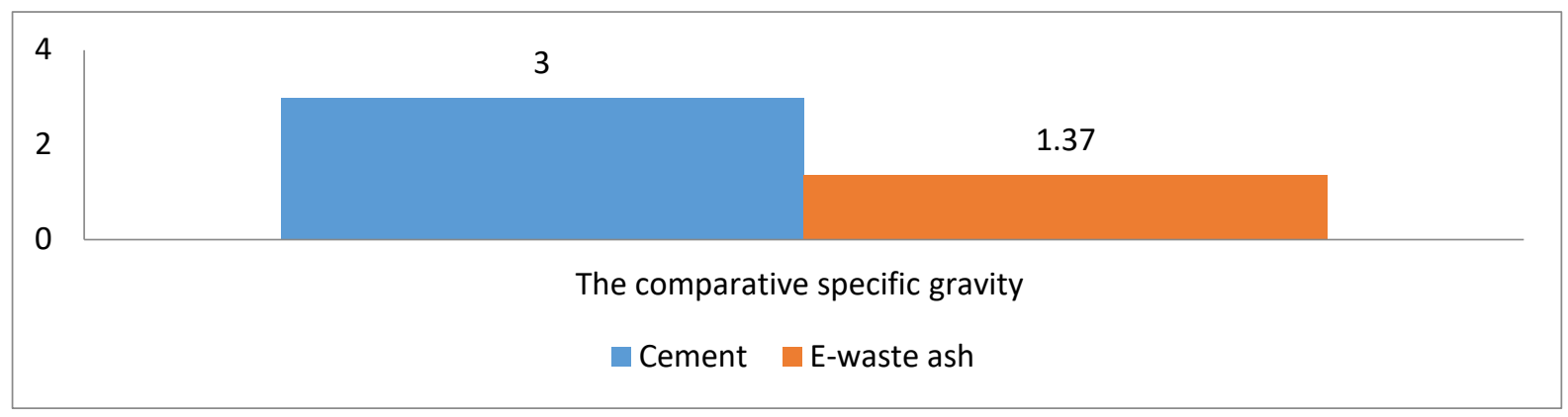

Figure 3: Comparative Specific Gravity Test Results of Plain Cement and E-waste Ash Cement Concrete the outcomes it very well may be seen that solid with over As appeared in Figure 5, the droop test aftereffect of plain bond cement and e-waste ash, bond concrete. The consistency of blend is tried by the droop test. By looking at $30 \%$ e-waste ash settles at an expansive sum than the plain concrete

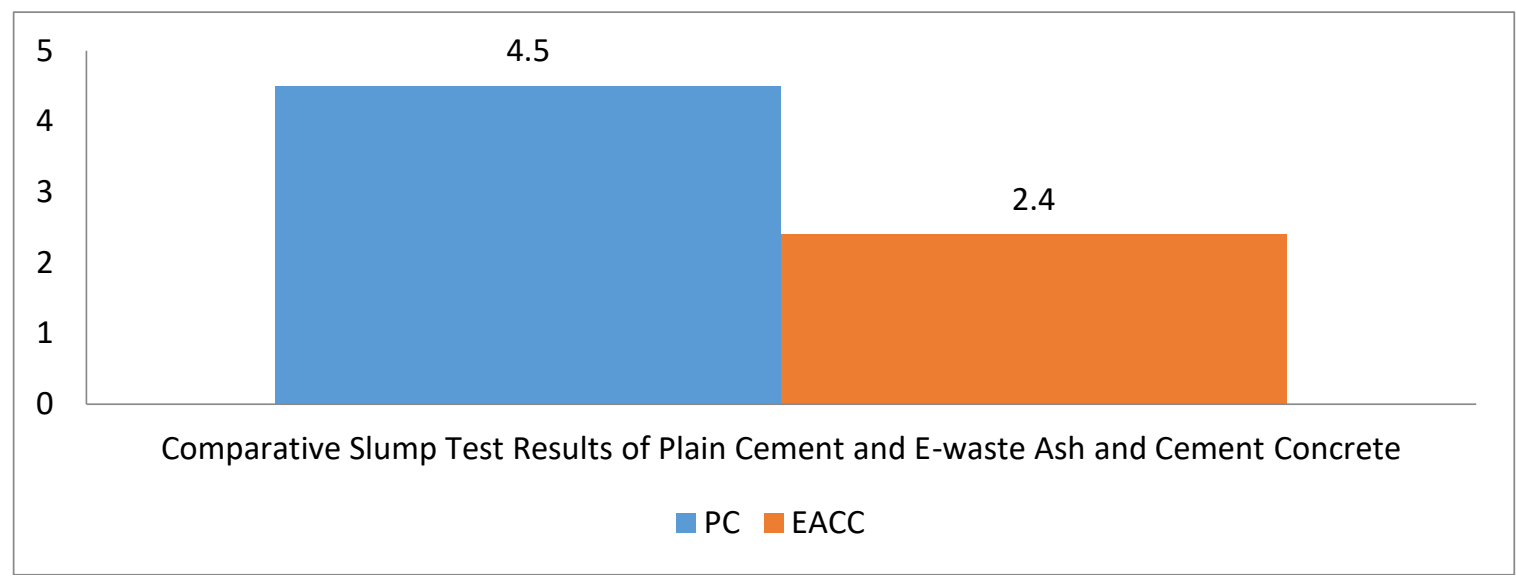

Fig 4: Comparative slump test results of plain and E-waste ash concrete

The flexural quality of an example is appeared Table Six. The flexural quality consequences of the E-waste ash remains cement concrete specimen are over the plain cement concrete [18]. At the essential testing, seven days of regular activity, the E-waste ash remains cement concrete accomplished very twofold the quality of the plain concrete cement. What's more, till the last testing, fourteen days of common activity, still the E-waste ash-cement concrete very double the quality of the plain cement concrete[21].

Table 5: Flexural Strength Test Result of Rectangular Specimens

\begin{tabular}{|c|c|c|c|c|}
\hline $\begin{array}{c}\text { Time } \\
\text { (days) }\end{array}$ & \multicolumn{2}{|c|}{ Plain Concrete } & \multicolumn{2}{c|}{ E-waste ash and Cement Concrete } \\
\hline \multirow{5}{*}{7} & $\begin{array}{c}\text { Ultimate } \\
\text { Load } \\
\text { capacity } \\
(\mathrm{KN})\end{array}$ & $\begin{array}{c}\text { Ultimate } \\
\text { Strength } \\
(\mathrm{Mpa})\end{array}$ & $\begin{array}{c}\text { Ultimate } \\
\text { Load } \\
\text { capacity } \\
\text { (KN) }\end{array}$ & $\begin{array}{c}\text { Ultimate } \\
\text { Strength } \\
\text { (Mpa) }\end{array}$ \\
\hline & 8.50 & 0.22 & 8.47 & 0.21 \\
\cline { 2 - 5 } & 4.78 & 0.45 & 5.70 & 0.40 \\
\cline { 2 - 5 } & 8.90 & 0.41 & 6.50 & 0.38 \\
\cline { 2 - 5 } & 10.22 & 0.45 & 8.45 & 0.40 \\
\cline { 2 - 5 } & 9.98 & 0.43 & 11.52 & 0.56 \\
\hline
\end{tabular}

The compressive and flexural quality versus the solidifying amount chart is appeared in Figures five, severally [19]. By examination the outcomes between plain concrete and Ewaste ash cement concrete example, it'll be discovered that the quality of e-waste ash cement concrete creates at a quicker rate than speed of the solidifying of the concrete blend [20]. E-waste Ash synthetically responds with lime made by the relationship of bond and water, along these lines detachment their voids that permit the development of status through the concrete [22]. $\cdot$ 


\section{Comparative Compressive Strength Test Results of Plain Concrete and e-waste Ash Concrete}

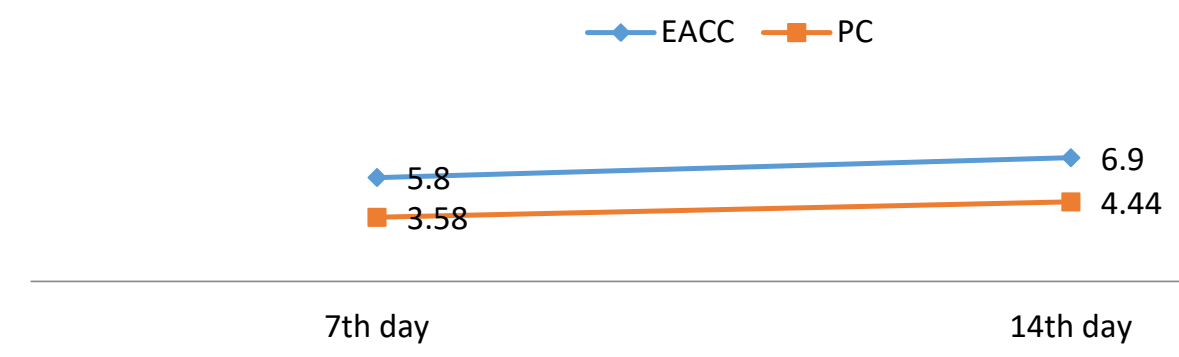

Fig 5: Comparative compressive strength test results of plain concrete and E-waste ash concrete

\subsection{Impact of e-waste ash}

3.3.1. Specific Gravity: E-waste ash incorporates a lower unit weight, which implies that on a gram for each gram premise, slag contributes generally additional plain concrete volume of curio per gram versus bond [23]. The bigger the offer of fiery debris at interims the glue, higher lubed the totals region unit and in this way the higher the concrete streams [24].

3.3.2. Consistency: E-waste ash remains diminishes the amount of water expected to give a given droop. The circular sort of the fiery remains particles and its dispersive capacity offer water diminishing qualities [25].
3.3.3. Flexural Strength: E-waste cinder keeps on consolidating with the lime in concrete, expanding flexural quality after some time. It enables the concrete blend to return through its most quality quicker [26].

3.3.4. Compressive Strength: E-waste ash remains keeps on joining with the lime in concrete, expanding compressive quality after some time. It enables the concrete blend to return through its most quality quicker [27].

3.3.5. Rate of Curing: E-waste ash remains can expands the speed of the solidifying of the concrete blend. E-waste powder artificially responds with lime made by the relationship of bond and water, in this way division their voids that change the development of the condition through the concrete [28].

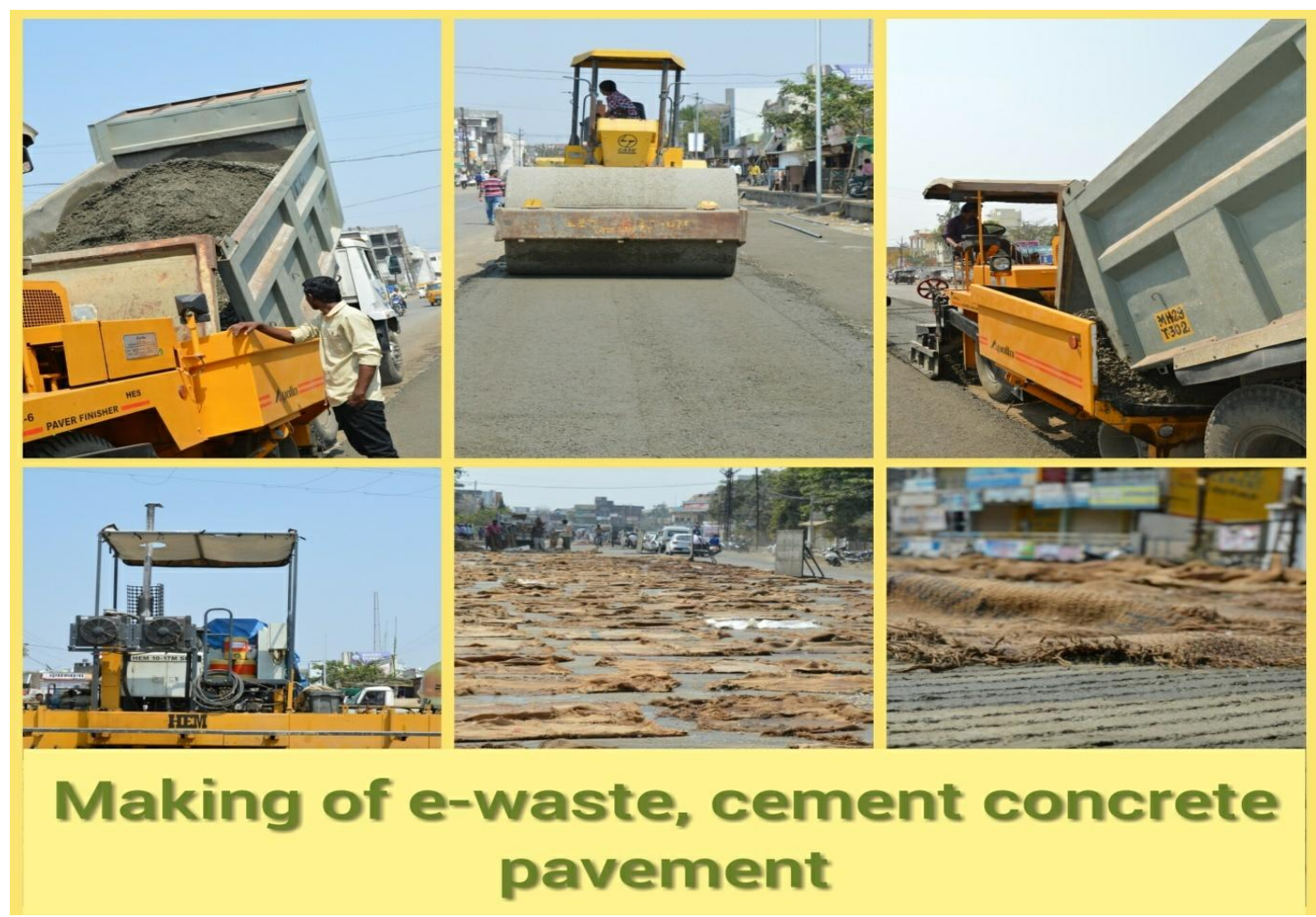

Fig 6: Processes involved in making e-waste and cement concrete pavement

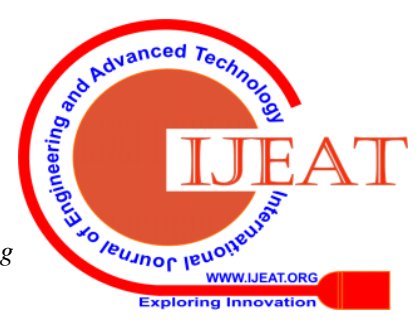




\section{CONCLUSION}

For a provided arrangement of resources in partner degree passing concrete blend, there's conjointly a bond content that creates a most concrete quality [29]. Therefore, on getting higher qualities one on the whole the chief insightful ways that will be that the use of ash among the blend ewaste ash proportioned exploitation the thoughts brief by this paper has been appeared to blessing qualities altogether on prime of these offered by a bond concrete [30]. The move of proportioning anticipated all through this paper grants for the usage of a larger than average change of $\mathrm{E}$ waste ash, it has been discovered that it isn't the nature of ewaste fiery remains that is vital yet the variety of that quality a portion of the mean [31]. Astute cement is normally proportioned containing partner degree intermittent quality fiery remains until the quality does not differs well [32]. The best favourable position for using of e-waste fiery remains in cement is that the obligation that it grants with the choice of the blend extents [33]. By utilization of the fiery remains, a curiously large shift of potential blends is regularly examined for any determination [34]. For each situation, it's capability to go to a choice on either the least worth blend, or the best to put, or the principal tough [35]. E-waste fiery debris contains a lower unit weight which implies the bigger the offer of ash among the glue, higher greased up the totals are thus the higher the concrete streams and keeps on consolidating with the lime in concrete, expanding compressive quality after some time. It enables the concrete blend to make a living its most quality quicker. This demonstrates e-waste fiery remains are regularly utilized viably as material in concrete road pavement [36].

\section{ACKNOWLEDGMENTS}

The authors are appreciative to Dr. Reena Panawane, Head of Civil building office at Jawaharlal Darda Institute of Engineering and Technology for their profitable help and giving testing results to do this exploration work.

\section{REFERENCES}

1. T. U. Ganiron Jr, "Scrap Waste Tire as an Additive in Asphalt Pavement for Road Construction", International Journal of Advances in Applied Sciences, vol. 1, no. 2, (2012), pp. 31-37.

2. T. U. Ganiron Jr, "Concrete Debris a Fine Aggregate for Architectural Finishing Mortar", Architectural Journal, vol. 2, no. 5, (2012).

3. R. L. Davison, "Trace Elements in Fly Ash, Dependence of Concentration on Particle Size", Environmental Science \& Technology, vol. 8, no. 13, (1974), pp. 1107-1113.

4. T. U. Ganiron Jr, "Effects of Rice Hush as Substitute for Fine Aggregate in Concrete Mixture", International Journal of Advanced Science and Technology", vol. 58, (2013).

5. T. U. Ganiron Jr, "Technical Specification of Concrete Hollow Blocks with Coconut Shells and Fiber as Aggregate", Proceedings of the 1st International Concrete Sustainability, (2013) May 27, Tokyo, Japan.

6. H. Vogg and L. Stieglitz, "Thermal behavior of PCDD/PCDF in Fly Ash from Municipal Incinerators", Chemosphere, vol. 15, no. 9, (1986), pp. 1373-1378.

7. T. U. Ganiron Jr, "Recycling of Waste Coconut Shells as Substitute for Aggregates in Mix Proportioning of Concrete Hollow Blocks", WSEAS Transactions on Environment and Development, vol. 9, no. 4, (2013).
8. K. L. Dreher, "Soluble transition metals mediate residual oil fly ash induced acute lung injury", Journal of Toxicology and Environmental Health Part A, vol. 50, no. 3, (1997), pp. 285-305.

9. T. U. Ganiron Jr, "Investigation on the use of Coco Coir Polypropylene as Thermal Insulator", International Journal of Advanced Science and Technology, vol. 59, (2013), pp. 13-26.

10. N. Shigemoto, H. Hayashi and K. Miyaura, "Selective Formation of Na-X Zeolite from Coal Fly ash by Fusion with Sodium Hydroxide Prior to Hydrothermal Reaction", Journal of Materials Science, vol. 28, no. 17, (1993), pp. 4781-4786.

11. A. Bilodeau and V. Mohan Malhotra, "High-Volume Fly Ash System: Concrete Solution for Sustainable Development", ACI Materials Journal, vol. 97, no. 1, (2000).

12. T. U. Ganiron Jr, "Technical Specification of Concrete Hollow Blocks with Coconut Shells and Fiber as Aggregate", Proceedings of the 1st International Concrete Sustainability, Tokyo, Japan, (2013) May 27.

13. M. Rýznarová, "Sorption of Dyes from Aqueous Solutions onto Fly Ash", Water Research, vol. 37, no. 20,

14. (2003), pp. 4938-4944.

15. G. Gupta, G. Prasad and V. N. Singh, "Removal of Chrome Dye from Aqueous Solutions by Mixed Adsorbents: Fly Ash and Coal", Water Research, vol. 24, no. 1, (1990), pp. 45-50.

16. C. Chrisp, L. Fisher and J. E. Lammert, "Mutagenicity of Filtrates from Respirable Coal Fly Ash", Science (New York, NY) 199.4324, (1978), pp. 73.

17. Tompkins, D., L. Khazanovich, M. Darter, and W. Fleischer. Design and Construction of 4 Sustainable Pavements: Austrian and German Two-Layer Pavements. Transportation 5 Research Record: Journal of the Transportation Research Board, No. 2098, 6 Transportation Research Board of the National Academies, Washington, D.C., 2009, pp.7 75-85.

18. National Ready Mixed Concrete Association (NRMCA), "What, Why, and How? Pervious Concrete", Concrete in Practice series, CIP 38, Silver Spring, Maryland, May 2004, 2 pages

19. National Ready Mixed Concrete

20. Association (NRMCA), "Freeze - Thaw Resistance of Pervious Concrete",Silver Spring, Maryland, May 2004, 17 pages

21. Ghafoori, N., and Dutta, S., "Building and onpavement Applications of No-Fines Concrete," Journal of Materials in Civil Engineering, Volume

22. Number 4, November 1995, pgs. 286-289.

23. Sri Ravindrarajah, R. and Aoki, Y., "Environmentally friendly porous concrete", Proceedings of the Second International Conference on Advances in Concrete and Construction, Hyderabad, India, Feb. 2008.

24. Richard c Meininger, " No Fines Pervious Concrete for Paving," Concrete Intenational Vol. 10, No. 8, August 1988, pp. 20-27

25. Montes, F., Valavala, S., and Haselbach, L.M. "A New Test Method for Porosity Measurements of Porland Cement Pervious Concrete," Journal of ASTM International, Vol. 2, No 1, January 2005, pp.13.Rushton B., "Infiltration Opportunities in Parking-Lot Design Reduce Runoff and Pollution”,Stormwater, 2002.

26. Park, S., Tia, M. (2004). "An experimental study on the waterpurification properties of porous concrete," Cement and Concrete Research, (Vol.34), pp.177-184.

27. http://www.concrete.org

28. http://www.concretenetwork.com/pervious/

29. Sneha Sanjay Ganpule, S. V. Pataskar (2011), "Use of Porous Concrete as a Green Construction Material for Pavement" International Journal of Earth Sciences and Engineering, ISSN 09745904, Volume 04, No 06 SPL, October 2011, pp. 764-767.

30. N. Murayama, H. Yamamoto and J. Shibata, "Mechanism of Zeolite Synthesis from Coal Fly Ash by Alkali Hydrothermal Reaction", International Journal of Mineral Processing, vol. 64, no. 1, (2002), pp. $1-17$.

31. S. Khare, "Removal of Victoria Blue from Aqueous Solution by Fly Ash", Journal of Chemical Technology and Biotechnology, vol. 38, no. 2, (1987), pp. 99-104.

32. ]T. U. Ganiron Jr and N. Ucol-Ganiron, "Recycled Glass Bottles: An Alternative Fine Aggregates for Concrete Mixture", Proceedings of the 4th International Conference of Euro Asia Civil Engineering Forum, Singapore, (2013) June 26-27.

33. Zeolites from Coal Fly Ash”, Fuel, vol. 78, no. 10, (1999), pp. 12251230 .

Blue Eyes Intelligence Engineering

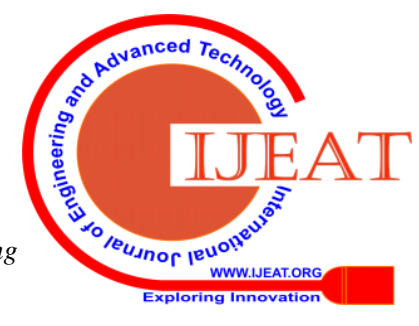


34. L. Stieglitz and H. Vogg, "On Formation Conditions of PCDD/PCDF in Fly Ash from Municipal Waste Incinerators”, Chemosphere, vol.16, no. 8, (1987), pp. 1917-1922.

35. C. Lin and H. Hsing-Cheng, "Resource Recovery of Waste Fly Ash: Synthesis of Zeolite-Like Materials", Environmental Science \& Technology, vol. 29, no. 4, (1995), pp. 1109-1117.

36. A. Chang, "Physical Properties of Fly Ash-Amended Soils", Journal of Environmental Quality, vol. 6, no. 3, (1977), pp. 267-270.

37. H. Nollet, "Removal of PCBs from Wastewater using Fly Ash", Chemosphere, vol. 53, no. 6, (2003), pp. 655-665.

\section{AUTHORS PROFILE}

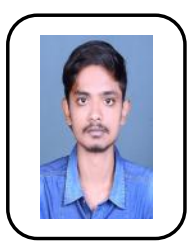

Aniket Ravindra Ingole, pursuing $M$ Tech. in Environmental engineering at G.H. Raisoni UniversityAmravati. Author of 5 books, Researcher and published more than 15 articles in reputed International journals.

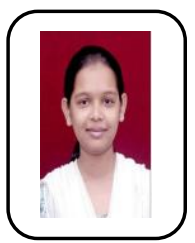

Shweta Kailashrao Gulhane $M$ Tech. in Environmental and Water resources from College of engineering Pune. Dissertation work entitled as Assessment of ground water potential zone using GIS approach in Pavna river Sub Basin in Pune district.

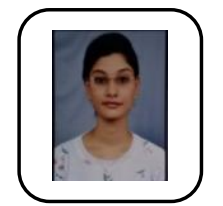

Shivani Sanjay Shirbhate, Final year student of Civil engineering at Jawaharlal Darda institute of engineering and technology-Yavatatmal.

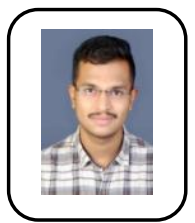

Mayur Pandit Chavhan, Final year student of Civil engineering at Jawaharlal Darda institute of engineering and technology-Yavatatmal

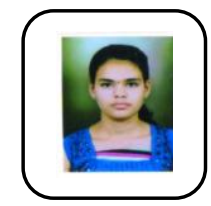

Toshini Narendra Makde Final year student of Civil engineering at Jawaharlal Darda institute of engineering and technology-Yavatatmal.

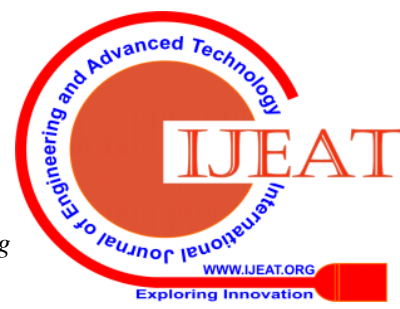

